色材, 69〔6]，413-421（1996）

\title{
E S R（電子スピン共鳴）
}

辻田隆広* ・岡本 信吾*

\section{1.はじめに}

自然界に存在する物質を磁性の観点から分類すると, 磁石としての性質を持つ物質すなわち常磁性物質と, 磁 石としての性質を持たない物質すなわち反磁性物質に大 別される。常磁性物質は自然界に普遍的に存在している ものであり, 高分子の劣化と密接な関係にある。常磁性 物質はいい換えれば不対電子を有する物質であり，この 場合, 着色顔料に多く含まれる遷移金属イオンや劣化過 程において発生する有機ラジカル, また大気中に存在す る酸素や分子状酸素と有機ラジカルが反応して生成する 酸素ラジカル（一般に活性酸素之呼ぶ）等を指す。この ような不対電子が存在する常磁性物質を対象とする測定 手段が ESR（電子スピン共鳴）である。

ESR スペクトルから求めた常磁性物質特有の（また は固有の）パラメーター（g 值と呼ぶ）により常磁性物 質周辺の電子状態が分かる。また, 外部からの刺激, 例 えば紫外線や酸素, 熱, 時には衝撃等を与えることに よって常磁性物質の経時変化を観測することができる。 高分子化合物においては, 例えば塗膜の光照射に伴う経 時変化を観測したりする。これらは素材の評価だけでは なく, 高分子素材の表面設計においても非常に重要な位 置づけになると思われる。そこで本文では始めに ESR スペクトルの解析に必要な原理や解析方法について紹介 し, 次に ESR を用いた塗膜への研究例を紹介する。

\section{ESRについて}

\subsection{ESR と測定対象}

ESR 測定装置は一般の分光機器と異なり, 測定部に

平成 8. 4.24 受理

Electron Spin Resonance

Takahiro T SUJ ITA and Shingo OКAMOTO

*日本油脂(株)塗料事業部技術本部

神奈川県横浜市戸塚区下倉田町 296（广244）
大きな磁石があるのが特徴である。すなわちマイクロ波 発生器と磁場を発生させる磁石の二つの部分に分かれて いる。この点ではNMR と類似している。ESR が周波 数（マイクロ波）を固定して磁場を掃引して測定する分 光法に対して, NMR は磁場を固定して周波数を掃引す る分光法である。ESR の主な測定対象としては以下に 示すものが挙げられる。

1) 有機ラジカル

2 ）遷移金属イオン

3 ) 酸素 (活性酸素)

有機ラジカルの歴史は古く, 20 世紀の初めにトリフェ ニルメチルラジカルが合成されて以来, 数多くの安定な 有機ラジカルが合成されてきた。ESR は有機ラジカル の検出と同定, 電子状態の研究に重要な役割を果してき た。最近ではスピントラップ剂, スピンラベル剂, スピ ンプローブ剤の合成技術の進歩により，より不安定なラ ジカル捕捉が可能になり ESR の応用分野が広がりつつ ある。有機ラジカルのうち不対電子が $\mathrm{p}$ 軌道に入って

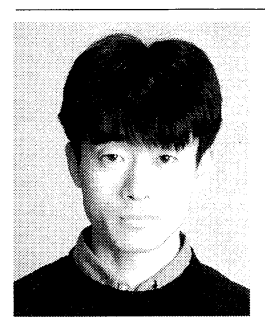

〔氏名〕つじた たかひろ

〔現職〕日本油脂(㑣塗料事業部

〔趣味〕スポーツ（テニス, 野球)

〔経歴〕1992 年愛媛大学理学部化学科 卒業, 同年日本油脂(㑣入社, 現 在に至る。

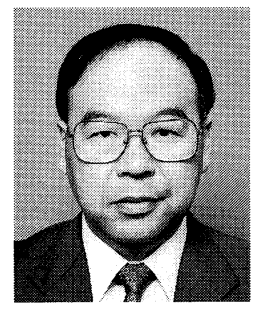

〔氏名〕おかもとしんご

〔現職〕日本油脂(㑣)塗料事業部 工業塗 料技術部長

〔趣味〕囲碁, 切手収集

〔経歴〕1973 年静岡大学工学研究科 (合成化学専攻) 卒, 同年日本 油脂(株)入社, 現在に至る。工学 博士。 


\begin{tabular}{|c|c|c|c|c|c|c|c|c|c|c|c|c|c|}
\hline & $1 \mathrm{~s}$ & $2 \mathrm{~s}$ & $2 p$ & & $3 \mathrm{~s}$ & $3 p$ & & $3 d$ & & & & & $4 \mathrm{~s}$ \\
\hline $\mathrm{Cu}$ & 11 & 14 & 1h & 11 1t & $1 /$ & 14 & 1t 11 & & 1 & $1 \mathrm{l}$ & 1 & 11 & 1 \\
\hline $\mathrm{Cu}^{+}$ & 1h & 1 & & $11 \quad 16$ & $1 \downarrow$ & $1 /$ & $12 \quad 16$ & & 1 & $1 \quad 11$ & $1 l$ & 116 & \\
\hline $\mathrm{Cu}^{2+}$ & 16 & 11 & & 任 14 & 1 & & 1h 11 & & $1 /$ & $1 \quad 1$ & 11 & & \\
\hline $\mathrm{Cu}^{3+}$ & $1 h$ & 11 & $1 \downarrow$ & 1h 11 & $1 h$ & 1h & 1t it & & $1 /$ & l 1 & $1 k$ & & \\
\hline
\end{tabular}

いるラジカルを $\pi$ ラジカル, $\mathrm{s}$ 軌道に入っているラジカ ルを $\sigma$ ラジカルと呼ぶこともある。また結合の切断の仕 方によって中性ラジカルやカチオンラジカル, アニオン ラジカルのように分けることもある。

遷移金属イオンの場合全てが常磁性を示すのではな く, 基底状態の電子配置において不対電子（ほとんどが $\mathrm{d}$ 軌道に入っている）を有することが条件である。例え ば銅イオンは自然界では $\mathrm{Cu}^{+}, \mathrm{Cu}^{2+}, \mathrm{Cu}^{3+}$ の 3 種類の 状態をとりうることが知られている。銅イオンの基底状 態の電子軌道状態は上の表のようになっており $\mathrm{Cu}^{+}$と $\mathrm{Cu}^{3+}$ には不対電子は存在せず, $\mathrm{Cu}^{2+}$ のみが 1 個の不対 電子を持つために常磁性を示す。さらに大気中に存在す る酸素分子も実は常磁性物質であり, その電子配置から 明らかなように独立した 2 個の不対電子を持つビラジカ ルの形をした常磁性物質である。酸素は生命にとって必 要不可欠のものであるが, 素材にとってはマイナスに㗢 くケースが多い。酸素がよ゙のような機構で生体や素材に 取り込まれているかが最近の重要な研究テーマになって いる。水よりも高いエネルギー状態にあるが, 化学的に は比較的安定に存在する。しかし熱, 光によって容易に 励起状態になる上に, 電子を容易に受け入れ還元生成物 を作る。これら酸素の活性化および，それに引き続いて 起こる化学反応がたとえば塗膜の天然曝露においてたえ ず進行すると考えられる。

有機ラジカルに酸素分子が反応してできた過酸化物ラ ジカル $(\mathrm{ROO} ・)$ や劣化因子として注目されている スーパーオキサイドアニオン $\left(\mathrm{O}_{2}^{-}\right)$も酸素ラジカルの 一種であり，これらを総称して活性酸素と呼んでいる。

\subsection{ESR の原理}

不対電子は周囲に磁場が存在しないときには物質中で 無秩序に配列している。そこへ磁場が一定方向にかかる と, 電子スピンは磁場の方向を中心軸として歳差運動を 生じ図-1 ${ }^{1)}$ のように磁場の方向に平行（ $\beta$ スピン）か, 逆平行 ( $\alpha$ スピン) に小磁石 $(\mu)$ の向きをそろえてし まい， $\alpha$ と $\beta$ スピンによるエネルギー状態に差が生じ て, 図-2 ${ }^{2)}$ に示したようにゼーマン分裂を起こす。電子

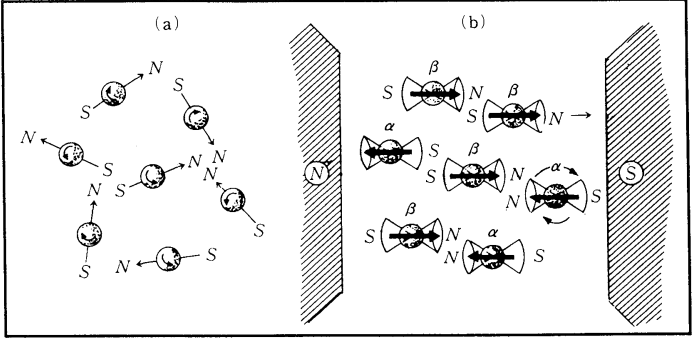

図-1磁場の中の電子スピン1)

(a) 外部磁場のない状態

（b）外部磁場がかけられた状態

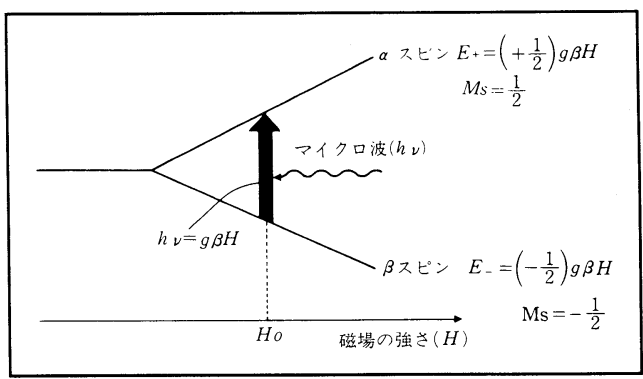

図-2 ゼーマン分裂1)

スピンのスピン量子数 Ms に対応するゼーマン準位の工 ネルギー差 $\mathrm{E}(\mathrm{Ms})$ は次の式で表される。

$$
\mathrm{E}(\mathrm{Ms})=\mathrm{g} \beta \mathrm{H}_{0} \mathrm{Ms}
$$

ここで $\mathrm{g}$ は電子スピンに特有の定数で $\mathrm{g}$ 值又は $\mathrm{g}$ 因子 （g-value 又は g-factor）と呼ばれている。1個の不 対電子が周囲の環境からまったく独立に存在している場 合（フリースピンという）には $\mathrm{g}=2.00232$ の值をも ち, 特に $g_{\mathrm{e}}$ と書かれる。 $\beta$ は電子の軌道運動によって 生じた磁気モーメントの最小単位でボーア磁子といわれ るものである。

$\beta$ スピンのエネルギー準位を例えば $(-1 / 2) \mathrm{g} \beta$ $\mathrm{H}_{0}, \quad \alpha$ スピンのエネルギー単位を $(+1 / 2) \mathrm{g} \beta \mathrm{H}_{0}$ とすると, このゼーマン分裂のエネルギー差は $\mathrm{g} \beta \mathrm{H}_{0}$ と表せる。このエネルギーと等しいエネルギーの電磁波 


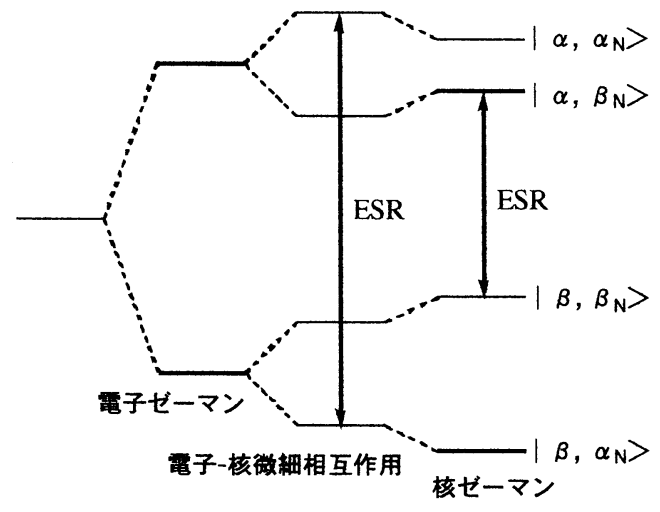

図-3 核スピン 1／2ののゼーマン分裂

（マイクロ波）エネルギー（h⿻）を照射すると，磁場 に平行にあった安定状態の $\beta$ スピンがそのエネルギーを 吸収して逆方向の不安定な $\alpha$ スピンに反転する。この現 象を ESR（電子スピン共鳴）といい，この現象を測定 する機器が ESR 測定装置である。このマイクロ波の吸 収の程度,つまりスペクトルの強さは二つの準位間に あった両スピン数の差 $(\beta-\alpha)$ に比例するのでこの差 の大きい条件，つまり測定温度が低くなるにつれてこの 差が増大する。したがって，ESR は温度依存性が大き いことが特徴であり同じ物質についても測定温度を变化 させることで, 様々な情報が得られることがしばしばあ る。

核スピン（I）が $1 / 2$ の場合のゼーマン分裂を図-3 に示した。量子化学的にスピンは $(+1 / 2)$ および $(-1 / 2)$ に分裂し，それぞれ電子スピンを $\alpha, \beta$, 核スピンを $\alpha_{\mathrm{N}}, \beta_{\mathrm{N}}$ とする。スピンは電子ゼーマン（電 子スピンのみの分裂）之核ゼーマン（核スピンのみの分 裂）および，電子一核超微細相互作用（電子スピンと核 スピンの相互作用による分裂）のそれぞれに分裂する。 電子スピンが $\beta$ からの $\alpha$ に遷移するところ $\left(\triangle \mathrm{M}_{\mathrm{s}}=\right.$ $1, \Delta \mathrm{M}_{1}=\mathrm{O}, \mathrm{M}_{\mathrm{s}}$ : 電子スピン量子数, $\mathrm{M}_{\mathrm{I}}$ : 核スピ ン量子数）で起こり, 矢印で示した二つの吸収が $\mathrm{ESR}$ の吸収として表せる。したがって水素ラジカルのような 核スピンが $1 / 2$ のフリーラジカルは， 2 本のESR 信 号が観測されるはずである。このように ESR は電子と 核の相互作用に基づく微細構造が表れるため電子スピン の存在する周辺の電子状態の情報を得ることができる。

\subsection{ESR スペクトルの解析方法}

ESR スペクトルは不対電子上に核スピン（I）を有す る $\mathrm{n}$ 個の原子が存在すると，そのスペクトルは（2nI
＋1）本に分裂する。例えば，・NOく（ニトロキシド ラジカル）の場合，核スピン $\mathrm{I}=1$ の窒素原子が 1 個有 するラジカルであるから $(2 \times 1 \times 1+1=3)$ 本に分 裂する。ESR スペクトルがこのような微細分裂構造 (hyperfine structure) を有する場合，核スピンとそ の数を予測しながら解析を行っていく。解析した結果が 正しいかどうかは市販のシミュレーションプログラム (例えば日本電子(㹯製) を用いてスペクトルのシミュ レーションを行い，実測のスペクトルと比較して良い一 致が得られるまで繰り返す。したがって同一スペクトル に 2 種類以上のラジカルが混在する場合は特に困難であ る。このような場合には，さらに差スペクトルを求めた り, 温度可変を行って安定なラジカルのみを残したりし て解析を行う。

$\mathrm{g}$ 值の帰属には磁場を補正するマーカーを使用する が, 通常マーカーとして TCNQ-Li $(\mathrm{g}=2.00252)$ や $\mathrm{MgO}$ 粉末中にドープされた $\mathrm{Mn}^{2+}$ （6 本線スペクトル で低磁場側から 3 本目の $\mathrm{g}_{3}=2.034, \quad 4$ 本目の $\mathrm{g}_{4}=$ 1. 981）が使用される (図-4 参照)。 $\mathrm{Mn}^{2+}$ の場合を例に して $\mathrm{g}$ 值の求め方を示す。 $\mathrm{Mn}^{2+}$ の 3 本目と 4 本目の磁 場の間隔が 86. 9gauss であるから, $1 \mathrm{~cm}$ 当たりの磁 場が得られ，マーカーと帰属するスペクトルの間隔をも のさしで計測し $\triangle H$ （gauss）を求めておく。ESR の 共鳴条件は式 1 で表される。

$$
\mathrm{h} \nu=\mathrm{g} \beta \mathrm{H}
$$

マーカーである $\mathrm{Mn}^{2+}$ の 4 本目の信号の共鳴周波数を $\nu_{0}, \mathrm{~g}$ 值を $\mathrm{g}_{0}$, 磁場を $\mathrm{H}_{0}$ とすると共鳴条件は式 2 で 表される。

$$
\mathrm{h} \nu_{0}=\mathrm{g}_{0} \beta \mathrm{H}_{0}
$$

式 2 より共鳴磁場 $\mathrm{H}_{0}$ は式 3 で表される。

$$
\begin{aligned}
\mathrm{H}_{0} & =(\mathrm{h} / \beta) \cdot\left(\nu_{0} / \mathrm{g}_{0}\right) \\
& =0.714489 \times 9392.4 / 1.981 \\
& =3387 \quad\left(\nu_{0} ; \text { 実測值使用 }\right)
\end{aligned}
$$

次に観測されたスペクトルの $\mathrm{g}$ 值を $\mathrm{g}_{1}$ ，マーカーから の磁場の差を $\triangle \mathrm{H}$ とすると共鳴磁場は $\left(\mathrm{H}_{0}-\triangle \mathrm{H}\right)$ で 表される。したがって $\mathrm{g}_{1}$ は式 4 で表される。

$$
\begin{aligned}
\mathrm{g}_{1} & =\mathrm{g}_{0} \cdot \mathrm{H}_{0} /\left(\mathrm{H}_{0}-\triangle \mathrm{H}\right) \\
& =1.981 \times 3387 /(3387-25) \\
& =1.995 \quad \text { (ただし } \triangle \mathrm{H}=25 \text { とする })
\end{aligned}
$$

（ただし $\mathrm{h}$ : プランク定数， レ : 共鳴周波数, $\mathrm{g}: \mathrm{g}$ 值, $\beta$ : ボーア磁子, $\mathrm{H}$ : 共鳴磁場を表す) 


$$
\mid \mathrm{Li}-\mathrm{TCNQ} \quad\left[\begin{array}{l}
\mathrm{NC} \\
\mathrm{NC}
\end{array} \mathrm{X}_{-}=\mathrm{C}_{\mathrm{CN}}^{\mathrm{CN}}\right]^{-} \mathrm{Li}^{+}
$$
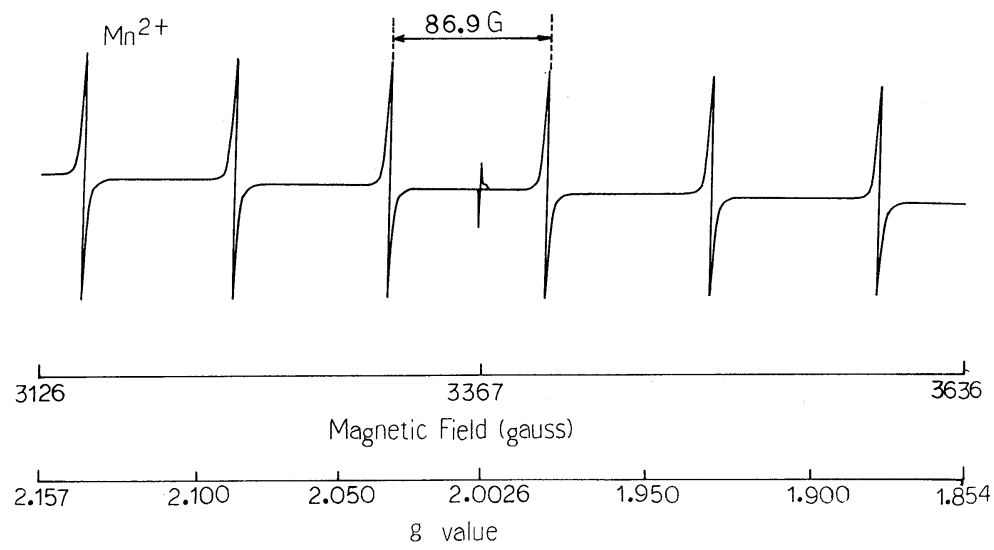

図-4 $\mathrm{Mn}^{2+}$ と TCNQ-Li のESR スペクトル

\section{ESR の塗膜への応用}

自動車, 電化製品, 建材等に使用されている塗膜は高 分子を主成分とする複合材料であり, 主成分である高分 子の寿命が塗膜の寿命を決定していると考えてよい。高 分子の劣化は自然条件としての光強度およびその波長, 湿度, 温度, 酸素によって決定される。この内温度は劣 化速度因子であり, 光エネルギー, 水, 酸素が劣化因子 となる。このため高分子の光劣化機構としては次のよう なラジカル反応が考えられている。A はクロモフォア (chromophore) を, $\mathrm{YH}$ は基質を, ${ }^{3} \mathrm{O}_{2}$ は基底状態 の 3 重項酸素を表している。

$$
\begin{aligned}
& \mathrm{A}+\mathrm{h} \nu \rightleftarrows \mathrm{A}^{*} \\
& \mathrm{~A}^{*} \longrightarrow 2 \mathrm{Y} \text {. } \\
& \left.\begin{array}{l}
\mathrm{YOO} \cdot+{ }^{3} \mathrm{O}_{2} \longrightarrow \mathrm{YH} \longrightarrow \mathrm{YOO} \\
\mathrm{YOOH} \longrightarrow \mathrm{YOOH}+\mathrm{Y}
\end{array}\right\} \text { 生成 } \\
& 2 \mathrm{YOO} \longrightarrow \text { Product } \\
& \text { 停止 }
\end{aligned}
$$

すなわち 1 個の光子 (photon : h $\nu$ ) が 1 個の結合切断 を引き起こして劣化の引き金となり，その結果としてラ ジカルが生成している。したがってラジカル量を見積も れば劣化の度合いが，ラジカル種を同定することにより 劣化機構が解明できることになる。

\section{1 塗膜の寿命予測}

ESR を用いた寿命予測の方法は大きく分けて 2 通り ある。一つはニトロキシドラジカルをスピンプローブと して用いる方法で, その ESR 信号強度の減衰速度から 高分子の劣化度あるいは耐候性を測定しょうとするもの

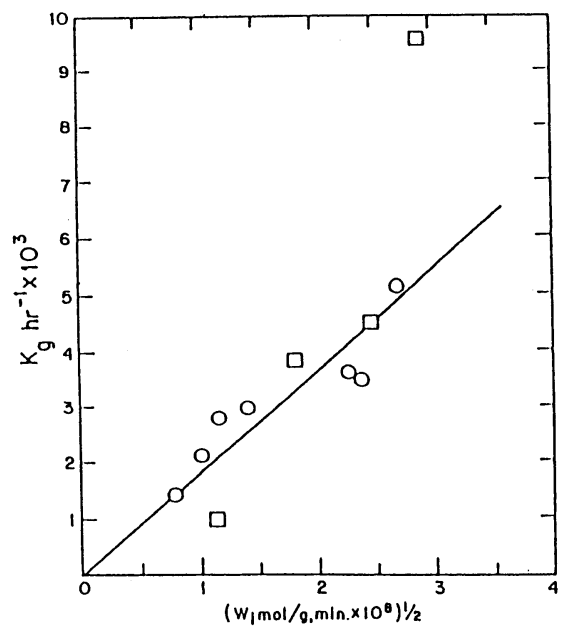

図-5 光沢減少速度 $(\mathrm{kg})$ と光劣化速度との相関2) ○;アクリルーメラミン系塗膜 $\square$; アクリルーウレタン系塗膜

である2)。Gerlock らは自動車用ハイソリッド塗料を検 討する上で，分子量の異なる 7 種類のアクリル樹脂を用 いて,メラミン硬化した塗膜 7 種類とイソシアネート硬 化した塗膜 4 種類の合計 11 種類の塗膜を生成し，塗膜 の光沢減少速度 $\mathrm{kg}$ とプローブとして用いたニトロキシ ドの減衰速度 $-\mathrm{d} 〔 \mathrm{NO} ・ 〕 / \mathrm{dt}$ の関係を求めた。光照 射により塗膜内に Y ・が生成すると次式によってラジ カルがニトロキシドとともに消失する。

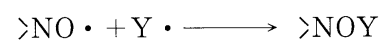


すなわちニトロキシド消失量がラジカル生成量に対応す る。ラジカル生成は結合切断, すなわちマクロ量として の光沢度と関係する。図-5に $\mathrm{kg}$ と $-\mathrm{d}[\mathrm{NO} ・ / \mathrm{dt}$ の関係を示す。ここで横軸は光劣化速度 Wi の平方根を 目盛ってあるが，これは- $\mathrm{d} 〔 \mathrm{NO} ・ 〕 / \mathrm{dt}$ に補正項を 加えたもので, 非常に良好な直線関係が得られている。

もう一つの方法は, 塗膜内に 5 \%程度含まれるビス フェノール $\mathrm{A}$ 型エポキシ樹脂が塗膜内に生成したラジ カル Y ・ と反応して安定なフェノキシルラジカル $(\mathrm{PhO} ・)$ になることを利用したものである3）。

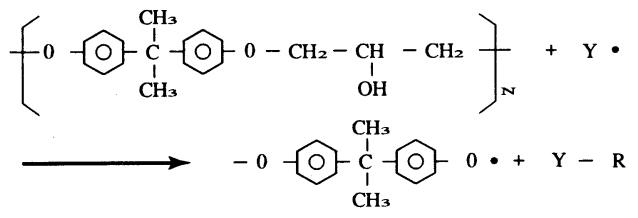

エポキシ樹脂がラジカルトラップ剂としての役割を果た し，Y・よりも安定なフェノキシラジカルになることが 示されている4)。

この ESR 信号の増加量を紫外線照射時間の関数とし てプロットして, 代表的な高分子塗膜の評価が行われて いる。シリコン変性度の異なる 4 種類のポリエステル樹 脂（シリコン変性度 : High, Medium, Low, Unmodified）の光照射によって生じるフェノキシルラジ カルの強度を時間の関数として示したのが図-6（a）で ある。シリコン変性度の高いものほどラジカル生成量が 少ない。他方これらの樹脂を用いて生成した白エナメル 塗膜の屋外暴露試験を行った結果を図-6（b）に示し た。 2 年後には, 変性度 High の光沢度が $85 \%$ を維持 したのに対して, Unmodified はすでに測定する価值 がないほど劣化していた。この変化の様子と（a）で示 した ESR 信号増加量とが定性的によい対応関係を示し ており,しかも 20 分と 2 年との差に注目したい。

図-6（a）で照射時間を無限大にした場合のラジカル 量を求めることも行われている5)。塗膜寿命がすでに 10 年とか 20 年とか判明している塗膜について, この収束 したラジカル量とを比較すれば, 塗膜から生じるラジカ 儿量を求めることにより塗膜寿命を決定できるはずであ る。図-6（a）は残念ながらフェノキシルラジカルの相 対濃度で表されているため絶対的なラジカル量を示して いない。絶対的なラジカル量を求めるためには, 塗膜か ら生じるラジカルスピン数が一つの目安となる。

熱可塑性フッ素樹脂/メチルメタクリレート樹脂系塗 膜に紫外線照射した時に生じるラジカルスピン数を求め
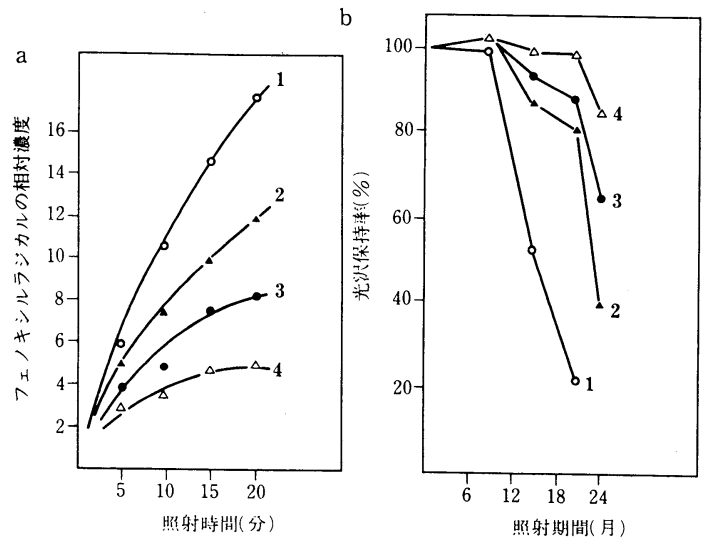

図-6 照射時間に対するフェノキシルラジカルの相 対濃度の変化と光沢保持率の変化 ${ }^{3)}$

ポリエステル中のシリコン量 : 1 濃度零, 2 低濃度, 3 中濃度, 4 高濃度

た例を紹介する ${ }^{6)}$ 。スピン数の標準物質として4-ヒドロ キシ-2, 2, 6, 6-テトラメチルピペリジン-1-オキシルを用 いた。スピン数の計算は得られた ESR スペクトル（微 分形で表されている）を全領域において 2 回積分を行 い, 試料サンプルの ESR 吸収強度とスピン数の既知物 質の ESR 吸収強度から比較する。吸収強度からスピン 数を計算するにはデーター処理装置として ESPRंIT330 （日本電子(森製）が便利である。フッ素樹脂含有量の異 なる 4 種類の塗膜（塗膜中のフッ素樹脂含有量 : 100 $\%, 70 \%, 30 \%, 0 \%)$ を用意し，10 分間の光照射を 行いながらラジカルスピン数を測定した。図-7 の横軸 は紫外線の照射時間を, 縦軸は塗膜 $1 \mathrm{~g}$ 当たりの生じた ラジカルスピン数を示している。フッ素樹脂含有量が 0 ,つまりアクリル樹脂単独から得られたラジカルスピ ン数は, フッ素樹脂を $70 \%$ 含有した塗膜から生じるそ れの 2 倍以上である。他方これらの樹脂を用いて作成し たエナメル塗膜の屋外暴露試験を行った結果を図-8に 示した。これらの結果よりラジカルスピン数は塗膜中の メチルメタクリレートの比率が高いほど多く生じてお り, かつラジカルスピン数は屋外暴露結果と良い対応を 示していることがわかる。

フッ素樹脂系塗料にはこれら紹介したフッ化ビニリデ ン系樹脂系のものと，フルオロエチレンとビニルモ） マーとを共重合させた樹脂（FEVE と略す）とがある が, FEVE 樹脂は最近では粉体塗料にも用いられてお り，溶剤形塗料と粉体塗料とを比較した実験もある7)。 図-9（a）に光照射 10 分間に生じるラジカルスピン数 


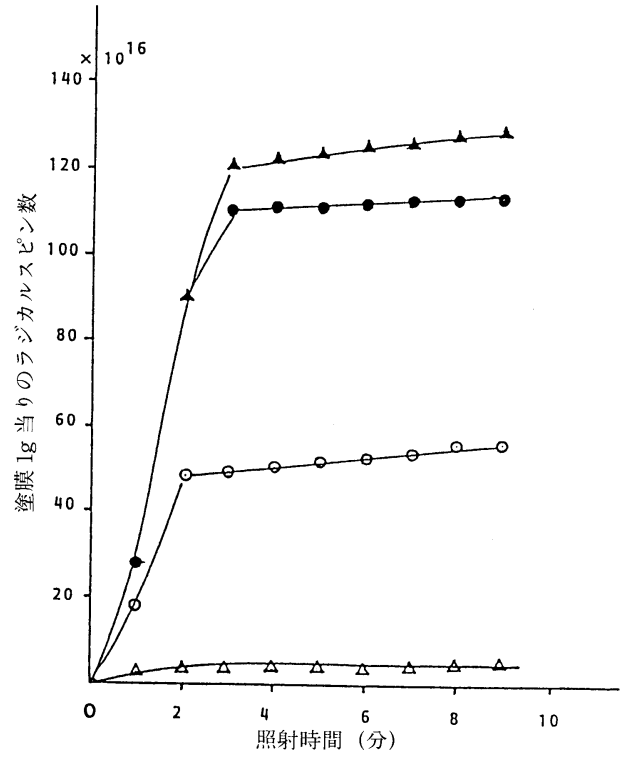

図-7 照射時間に対する塗膜から生じるラジカルス ピン数 $\left(\mathrm{N}_{2} \text { 気流中 }\right)^{6)}$ 。

フッ素樹脂含有量 : $\boldsymbol{\Delta}(0 \%), \boldsymbol{O}(30 \%)$,

$\bigcirc(70 \%), \triangle(100 \%)$

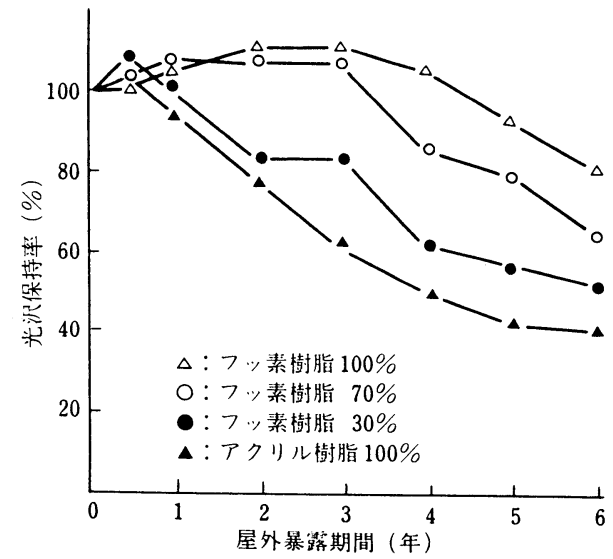

図-8 4 種類の塗料の屋外暴露結果 ${ }^{6)}$

の比較を, 図-9（b）にこれら 2 種類の白エナメル塗膜 5 年間の屋外暴露結果を示した。 5 年間の屋外暴露結果 では，いまだ 2 種類の塗膜の間で優劣をつけられる段階 ではないが，ラジカルスピン数から判断する限り，2 種 類の塗膜でははっきりと差が生じていると考えられる。

またエポキシ樹脂をラジカルトラップ剂に利用して, 紫外線吸収剤の良否 ${ }^{8}$ の評価法にも展開されている。

\section{2 塗膜劣化機構の解明}

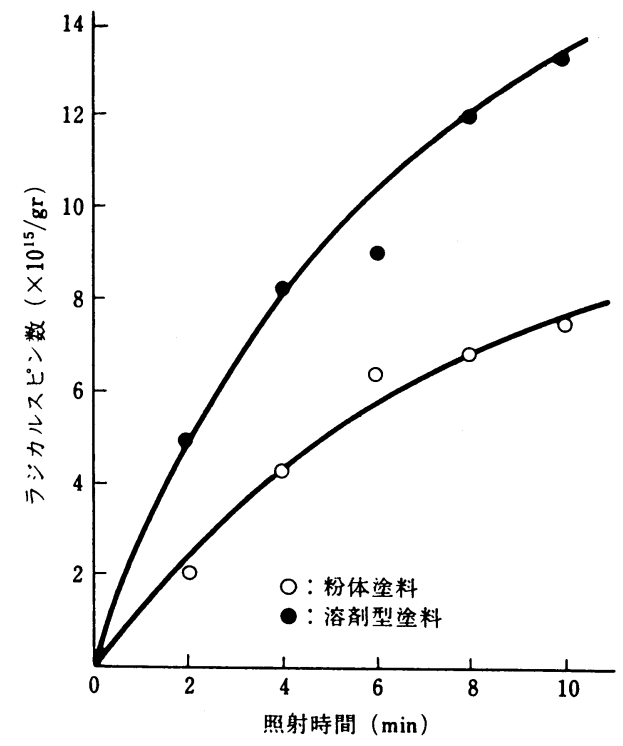

図-9（a ）フッ素粉体塗料と溶剂型フッ素塗料とか ら生じるラジカルスヒン数 ${ }^{7)}$

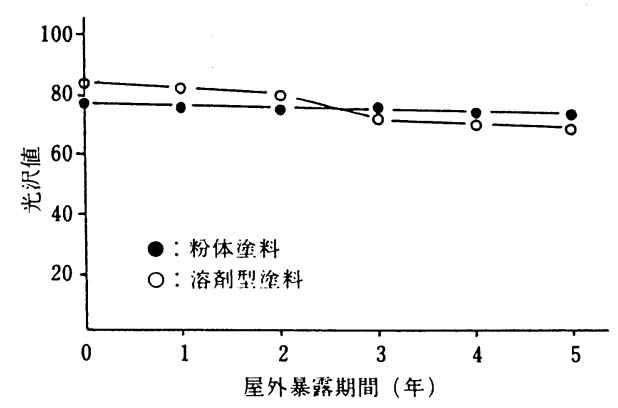

図-9（b ）フッ素粉体塗料と溶剂型フッ素塗料との 屋外暴露試験 ${ }^{7)}$

アクリル樹脂系塗膜と, $\mathrm{FEVE}$ 系フッ素樹脂塗膜の 劣化機構の解明に ESR が利用されている。ラジカル種 を同定するためには，ESR スペクトルの hyperfine 構 造 (分裂の本数と分裂の間隔, 特に分裂の間隔を超微細 結合定数と呼び，一般に a 值で表す）と $\mathrm{g}$ 值が重要で ある。hyperfine 構造を得るために液体窒素中（-196 C) で ESR 测定を行うことが多い。

メタクリレートモノマーとスチレンとからなるメタク リレート系塗膜を液体窒素中に浸し，紫外線照射しなが ら ESR 測定を行うと，スチレン量が増加するに従い hyperfine 構造が明確に表れてくる(図-10) ${ }^{9)}$ 。このス 


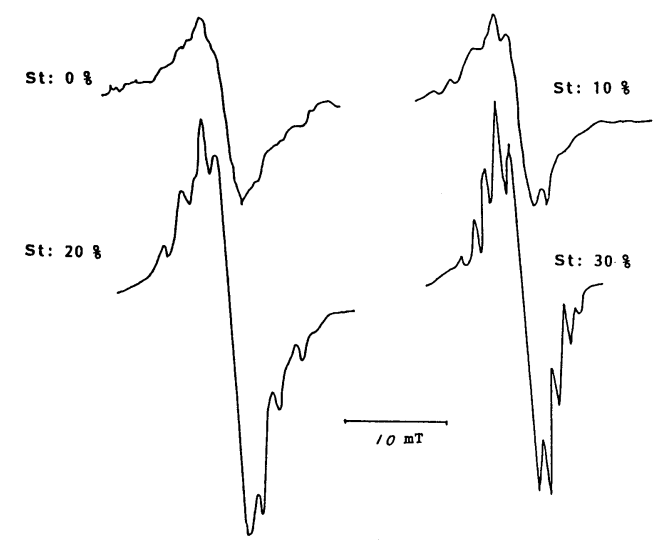

図-10 スチレン量の異なる塗膜から生じる ESR スペクトル ${ }^{9)}$

(照射時間30分, 测定温度 $-196^{\circ} \mathrm{C}$ )

上段 左(スチレン $0 \%$ ), 右(スチレン10\%)

下段 左(スチレン20\%),右(スチレン30\%)

ペクトルは 9 本線スペクトルで $\mathrm{a}=1.125 \mathrm{mT}$ であるこ とと, さらなる研究結果から $-\mathrm{CH}_{2} \mathrm{C}\left(\mathrm{CH}_{3}\right) \mathrm{COOR}$ と ・ $\mathrm{CH}_{3}$ ラジカルとの混合ラジカルであることが判明し た。さらに同一塗膜から・H ラジカルも見いだされて おり,これらの結果と FT-IR の結果とを総合して, メ タクリレート系塗膜の劣化機構を解明している。しかし ながらメタクリレート系モノマーとアクリレート系モノ マーおよびスチレンモノマーの混合系樹脂が塗料では一 般的に用いられている。

アクリレート系モノマーが存在すると, 重合開始剤を 変化させても図-11 (b) ${ }^{10)}$ に示した 5 本線スペクトルで $\mathrm{a}=1.15 \mathrm{mT}$ の $-\mathrm{CH}_{2} \dot{\mathrm{C}}(\mathrm{COOR}) \mathrm{CH}_{2}-$ ラジカルが生じ る。つまり混合系モノマーを使用したアクリル樹脂系塗 膜では最初に, アクリレートの水素引抜き反応が起こる のに対して, メタクリレート樹脂系塗膜ではメタクリ レートモノマーとスチレンモノマーとの間の結合切断が 起きて劣化していくことが確かめられた。

FEVE フッ素樹脂系塗膜を, 液体窒素中で光照射し ながら ESR 测定を行うと ${ }^{11)}, 5$ 本線 or / and 6 本線 と見られる微細分裂が観測される（図-12(a))。この 場合に 6 本線であると仮定して，2 個の等価な F 原子 の結合定数 $\left(\mathrm{a}_{\mathrm{F}}=35.2 \mathrm{gauss}\right), 1$ 個の $\mathrm{F}$ 原子の結合定 数 $\left(\mathrm{a}_{\mathrm{F}}=33.1 \mathrm{gauss}\right), 2$ 個の等価な $\mathrm{H}$ 原子の結合定数 $\left(\mathrm{a}_{\mathrm{H}}=20.7\right.$ gauss $)$ および $\mathrm{H}, \mathrm{F}$ の核スピン $\left(\mathrm{I}_{\mathrm{H}}=1 /\right.$ 2， $\left.\mathrm{I}_{\mathrm{F}}=1 / 2\right)$ をそれぞれコンピューター入力をして シミュレーションを行うと図-12（b）が得られた。図-

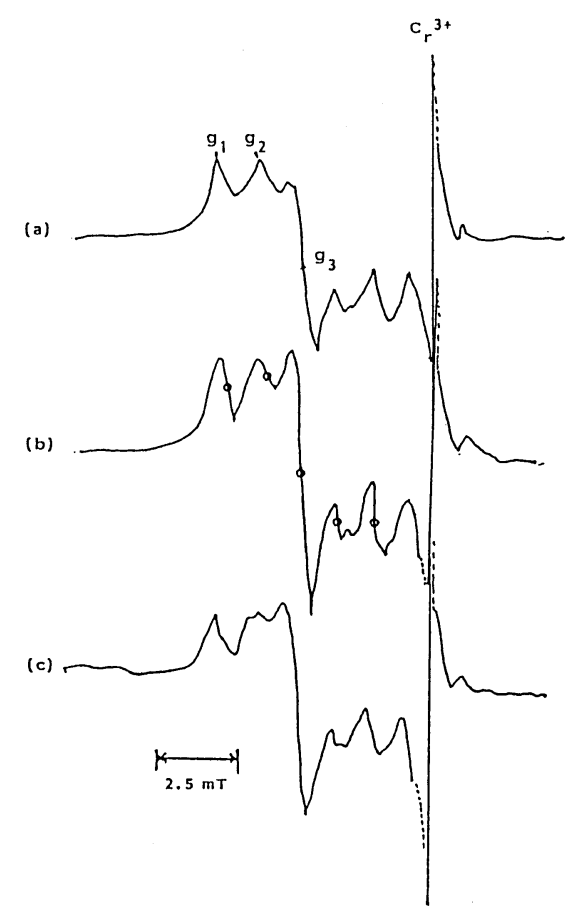

図-11 異なる重合開始剤を用いたアクリル樹脂塗 膜の ESR スペクトル（照射時間30分，測 定温度 $\left.25^{\circ} \mathrm{C}\right)^{10)}$

重合開始剤：（a）t-ブチルパーオキシベ ンゾネート

(b) ジメチルアゾビスイソ シアネート

(c) t-ブチルパーオキシラ ウレート

12 （b）は（a）のスペクトルの一部と一致することか ら, 図-12（a）のスペクトルの中には- $\mathrm{CF}_{2} \dot{\mathrm{CFCH}}{ }_{2} \mathrm{CH}$ ( $\mathrm{OR}) \mathrm{CF}_{2}-$ (ラジカル A とする) が含まれていると判 断できる。しかしながら詳細に比較すると， 3 本目の信 号強度と中心付近のスペクトルの違いが見いだされる。 このため図-12（a）のスペクトルから図-12（b）のス ペクトルを差し引くと図-13の 5 本線スペクトルが得ら れ, 結局図-12（a）のスペクトルはラジカル A と

$-\mathrm{CF}_{2} \mathrm{CF}(\mathrm{Cl})-\mathrm{CH}_{2}-\dot{\mathrm{C}}(\mathrm{OR})-\mathrm{CF}_{2}-($ ラジカル B とする) との混合ラジカルであると解析された。

温度可变測定を行うと, その測定温度におけるラジカ ルの安定性の違いから一種類のみのラジカルが測定され ることがある。 $263 \mathrm{~K}\left(-10^{\circ} \mathrm{C}\right)$ から徐々に温度を下げ て $213 \mathrm{~K} \quad\left(-60^{\circ} \mathrm{C}\right)$ まで測定すると図-14 (d) の超微 細構造のはっきりしたスペクトルが得られた ${ }^{12)}$ 。スペク 


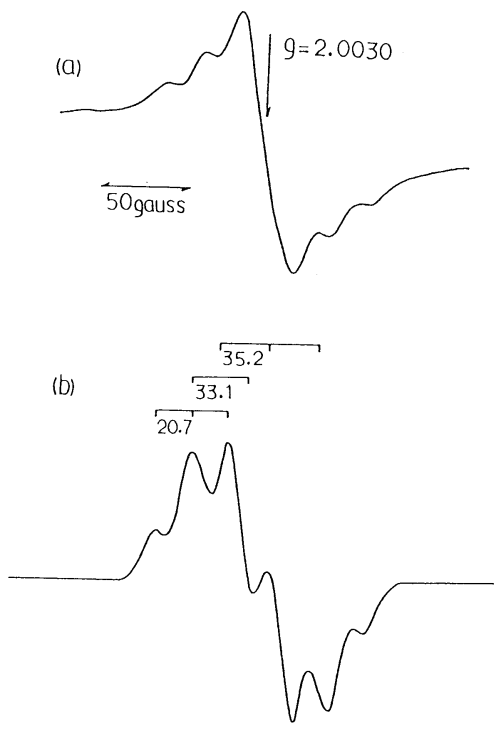

図-12 FEVE フィルムの実測スペクトルとシミュ レーションスペクトル ${ }^{11)}$

(a) 実測スペクトル（キセノンランプ 30 分照射, $77 \mathrm{~K}$ )

(b) シミュレーションスペクトル

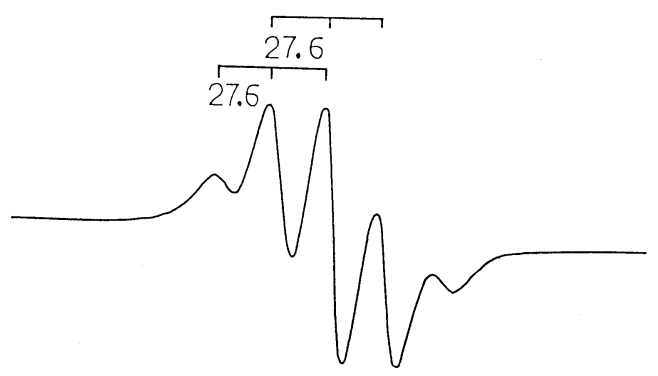

図-13 FEVE フィルムの実測スペクトルとシミュ レーション

スペクトルとの差スペクトル（シミュレー ションによる) ${ }^{11}$

トルの対象性から $\mathrm{g}_{1}$ の対象関係にあるのは $\mathrm{g}_{5}$ スペクト ルであり, $\mathrm{g}_{1} \sim \mathrm{g}_{5}$ の信号強度比は $1: 4: 6: 4: 1$ から,このスペクトルは $\mathrm{g}_{1} \sim \mathrm{g}_{5}$ の 5 本線スペクトル

（ラジカル B に相当する）と $\mathrm{g}_{6}$ に起因するスペクトル の混合スペクトルであると結論づけられている。つまり $\mathrm{FEVE}$ フッ素樹脂系塗膜の場合, 光照射によってラジ カル $\mathrm{A}$ とラジカル $\mathrm{B}$ とが生じて劣化していくことが判 明した。

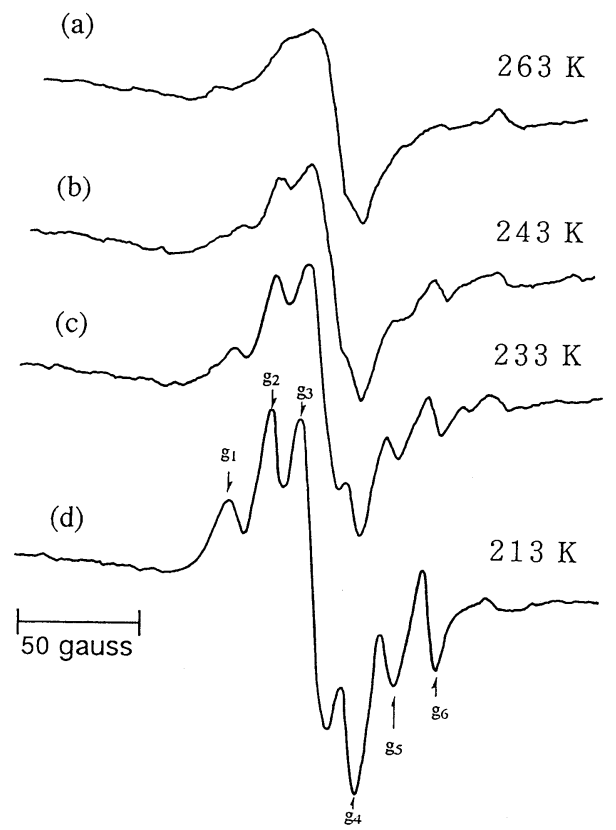

図-14 温度変化にともなう FEVE フィルムの ESR スペクトル12)
(a) $263 \mathrm{~K}$, (b) $243 \mathrm{~K}$, (c) $233 \mathrm{~K}$,
(d) $213 \mathrm{~K}$

\section{4. 後 記}

ESR が塗膜寿命予測や塗膜劣化機構に応用できるこ とを述べた。しかし残念ながらラジカルスピン数（ラジ カル量）から塗膜の正確な寿命を予測するにはデーター があまりに少なすぎる。今後も関係者の積極的な研究を 期待したい。最後に ESR をもっと勉強したい読者のた めに参考図書をあげる。

1)「ESR スペクトルの実際」桜井弘著, 廣川書店

2 )「電子スピン共鳴」大矢博昭 ・ 山内淳著, 講談社 サイエンティフィク

3)「実用 ESR入門」名津和彦編, 講談社サイエン ティフィク

4 ）「ESR 顕微鏡」池谷元同, 三木俊克著, シュプリ ンガーフェアラーク東京

5 )「素材の ESR 評価法」大矢博昭・山内淳編著, (株)アイピーシー 


\section{参考文 献}

1）桜井弘：「ESR スペクトルの実際」pp.13〜 14, 廣川書店,（平成元年）

2) J. L. Gerlock, D. R. Bower, L. M. Briggs, R. A. Dickie : J. Coating Tech., 57 [722], 37 (1985)

3）岡本信吾, 正田淳, 大矢博昭 : 鉄と鋼, 72, 1798 (1986)

4）岡本信吾, 㱜田淳, 大矢博昭：色材, 57, 49 (1984)

5) S. Okamoto, H. Ohya-Nishiguchi : European Coating J., 3, 205 (1989)

6) 岡本信吾, 大矢博昭：色材, 63〔7], 392 (1990)

7) T. Suzuki, S. Sagawa, T. Tsujita, S. Okamoto : Surface Coatings International, 3, 96 (1995)

8) S. Okamoto, K. Hikita, H. OhyaNishiguchi : Polymers Paint Colour J., 177 [4200], 683 (1987)

9）疋田淳, 岡本信吾, 大矢博昭：色材, 58〔6], 323 (1985)

10）岡本信吾 : 色材, 62 [7], 404 (1989)

11）辻田隆広, 鈴木貞一, 佐川千明, 岡本信吾 : 色 材, 67〔8]，484(1994)

12）辻田隆広, 鈴木貞一, 佐川千明, 岡本信吾 : 色 材, 68〔7], 389 (1995)

\section{用 語 解 説}

「スピントラップ剂」「スヒンラベル剂」「スピンプローブ剂」 スピントラップ法とは, 不安定なラジカル種を比較的安定な ラジカル種に変換して ESR 測定を行う方法である。スピント ラップ剂そのものは不対電子を持たない。スピントラップ剂と してはニトロン系とニトロソ系があるがフェニル-t-ブチルニト ロン（PBN）は代表的トラップ剂である。

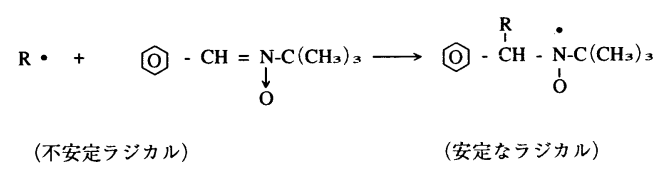

これに対して，スピンラベル法とスピンプローブ法は ESR 測定できない反磁性物質をスピンをもった物質により常磁性化 して ESR 測定を行う方法である。両方ともにニトロキシドラ ジカル（ンNO・）が使用される。スピンラベル剤（試薬）は対 象物に結合させて使用するため, 使用目的に応じて特別に工夫 された置換基を有し, 対象物と化学反応させる必要がある。そ れに対してスピンプローブ剂は, 対象物中にプローブ剂を混入 ・分散させれば良い。

このためビスフェノール A 型エポキシ樹脂は, スピントラッ プ剂の一種である。 